Rasim M. Alguliyev', Ramiz M. Aliguliyev ${ }^{2}$, Rahila Sh. Hasanova ${ }^{3}$

${ }_{1,2,3}$ Institute of Information Technology of ANAS, Baku, Azerbaijan,

${ }^{1}$ r.alguliev@gmail.com, ${ }^{2}$ r.aliguliyev@ gmail.com, ${ }^{3}$ rahasanova@ gmail.com

\title{
A METHOD FOR PRELIMINARY EXAMINATION OF DISSERTATIONS
}

The article explores the international practice regarding the assessment of dissertation works. A method is proposed for automated assessment of dissertation works. In this regard, algorithms are developed for the automation of pre-examination. This method allows to determine the similarity of essential parts of the dissertation (the goal of dissertation, its tasks, chapters, obtained results, and published papers) automatically. For this porpose text mining technology that allows to define the semantic proximity of the texts is applied. An assesment is given to determine the accordance between proposed method and expert assessment.

Keywords: dissertation thesis, text mining, automated assesment, expert assesment, fuzzy evaluation.

\section{Introduction}

A dissertation is a product of the scientific activity. Dissertation is an individually written scientific work exhibiting new scientific evidence and the contribution of an author to science [1]. Doctoral dissertation must be constructed from novel scientific and practical results and recommendations. In general, dissertation must be a scientific work responding to one of the following 2 clauses which characterize the outcomes:

- The dissertation must present new techniques which have a major importance for a specific scientific field;

- Technical, economic or technological developments must be scientifically justified presenting the solution for important applied problems in dissertation.

An accurate and correct assessment of one of the clauses characterizing the results of dissertation may help to improve the quality of researcher's work significantly.

The propositions presented by an author and solution techniques are to be rigorously justified, proven and critically assessed in comparison with already known solution methods.

While writing a dissertation, researcher must refer to authors and sources of materials and independent results of references. Authors and sources of used materials must be indicated at the end.

An examination must be carried out based on various indicators in order to determine whether a dissertation is developed by an author or "writer".

Which indicators can be included while determining the indepence of PhD student's work? According to experts, the following interrelated parameters are to be included [2]:

- Temporary limitation. The career of a public politician, entrepreneur, public servant, high-rank manager or general does not require a long-term departure from professional activity. So that, the preparation of dissertation requires sufficiently long time. It is no coincidence that, minimum 3 years are given for this purpose and significantly large number of doctoral candidates are not able to complete their works within the predetermined period according to official statistics.

- Work place of PhD student. This indicator is closely linked to the above mentioned issue. According to experts, the writing of dissertation by order is mostly done by those who have no relation to academic activity.

- The popularity of scientific researcher (an author presenting own work for obtaining the scientific title) in academic community. The status of dissertation work of an author is to be discussed with colleagues and their approval or critique (negative assessment) 
must be accepted. Otherwise, there is a basis for doubts regarding the authorship in doctoral dissertations.

- Possession of scientific terminology. The preparation for dissertation defense helps the dissertant to acquire the methodology and method within the framework of the direction of specific field of science.

- Text of dissertation. The style of writing of dissertation must be consistent (inseparable). The presence of two or more styles indicates the presence of several "writers" of dissertation.

- Publication. Main propositions (theses) of any dissertation must be published; a monograph is to be presented ahead during the dissertation defense.

- Time intervals between defenses of doctoral dissertations. It is reckoned that, this interval must be sufficiently large.

- Connections in scientific community. The closer the scientific researcher to Scientific community, the higher the probability that the author will receive positive feedback during the defence.

These are the main requirements posed to a dissertation work. Depending on the level of satisfaction of these requirements, it is possible to evaluate the quality of a dissertation. The main purpose in this regard is to determine the main point of dissertation work and hence, to provide an opinion whether this dissertation work can be a result of scientific activity.

It is clear that, the assessment of dissertation work is a hard work requiring a lot of time and attention and based on expert opinion. Till today, an automated preliminary examination and analysis of dissertation work has not be considered, it has not been assumed that, the content can be determined by employing a computed software. This assessment has always been subjective.

\section{Related works}

The principles of writing and assessment of a dissertation work is one of the broadly investigated fields in scientific activity [3-8].

This article considers several issues to be paid attention to while being accepted to doctoral studies: for instance, the selection of an institute or scientific field, awareness of the difference between master and doctoral studies, the purpose of doctoral studies, etc.

The reasons behind the issue of not succeeding to become a doctor of philosophy are various such as the lack of articles, proposal of new job position before obtaining the doctoral degree and etc. Moreover, doctorants (PhD students) are to be aware of the issues of how to communicate with scientific supervisor and what a supervisor expects from doctoral students: for instance, the independence of students, the written work of a student is not the first priority project, to be accurate and responsible, to consider the recommendations of supervisor, etc.

The necessary criteria of high-quality and poor-quality dissertation works are listed in [912]. High quality dissertation works possess the following qualities: critical analysis, self-reliance, strict and critical approach, scientific contribution, originality, creativity, compherensiveness and scientific approach, solid representation and structure, rigorous methodology. Poor-quality dissertation works possess the following characteristics: excessive details which are not analysed, poor presentation, non-rigorous methodology, etc.

Assessment of dissertation works in Norway based on different systems of three countries (USA, England, Sweden) is described in [13]. The purpose of this approach is to not only reveal strong and weak features of Norwegian assessment system, but to reveal weak aspects of the assessment system in mentioned countries. The assessment criteria used in these four systems: the jury of assessment committee, the status of published dissertation work, pre-examination assessment, examination and defense have been compared.

European countries are interested in high-quality doctoral education. Surely, the implementation of Bologne system has given an impetus for renewing the national assessment 
system. It is necessary to develop the indicators assessing the quality and effectiveness of doctoral education system. The doctoral program does not only base upon the preparation of national research financing systems, scientific workers and doctoral programs, but at the same time, on international cooperation and mobility as well [14-16].

The number of articles required for writing a dissertation work is very important as well. The large number of co-authored articles has become a norm in doctoral dissertation works in the field of natural and medical sciences; however, the role of the plaintiff and his/her co-authors is not clear. During the assessment, only the number of articles is important and the doctoral candidate is only required to be the main author of co-authored articles. The authorship ratio of each doctoral candidates has been harmonically calculated in two universitites in Scandiavia in 2008 in [17] article devoted to this topic. Harmonic calculation corrects the faults of existing methods and allows for the bibliometric analysis of the authorship ratio with high accuracy. The unbiased assessment of the authorship ratio of graduates and their co-authors provides the bibliometric assessment of modern doctorate requirements and creates a foundations for scientific productivity required (1.6 inseparable article corresponds per one dissertation work). While compared to previous data, it can be assumed that, the decline in the number of entered articles and larger number of co-authors has boosted some changes in last two decades. This article also explores solution techniques for this problem [17].

The assessment process of a dissertation work has gained interest in recent times. The paper [18] lists 12 important criteria for assessment dissertation works, for example, the contribution of dissertation work to science, bibliography, approach and methodology, analysis and results, presentation etc. Thereafter, the dissertation works are assessed by experts according to the abovelisted criteria.

The paper [19] is devoted to assessment of the dissertation works and an impact of reviewer's nature on the assessment. The variety of assessment has been carried out by employing the multidimensional concept of the dissertation works quality. In particular, impact of the relation to scientific supervisor, the expereince of organizations and higher education institutions, reviewer's affiliation on the assessment of dissertations has been explored. Based on practice, it is revealed that, the experience of regional organizations and committee members have a direct impact on the quality assessment, whereas the relation to scientific supervisor plays a negligible role in this regard.

\section{Proposed method}

Dissertation representation. The dissertation is perceived as chapters, articles published in journals, papers published in conference proceedings, the results obtained in a dissertation, the posed tasks and the goal. Denote a set of chapters as $\mathbf{S}=\left\{S_{1}, \ldots, S_{s}\right\}$, a set of published journal articles on dissertation topic as $\mathbf{A}=\left\{A_{1}, \ldots, A_{a}\right\}$, set of conference papers as $\mathbf{C}=\left\{C_{1}, \ldots, C_{c}\right\}$, set of obtained results in a dissertation as $\mathbf{R}=\left\{R_{1}, \ldots, R_{r}\right\}$, set of posed tasks as $\mathbf{P}=\left\{P_{1}, \ldots, P_{p}\right\}$ and the goal of dissertation work as $\mathbf{G}$. Consider each of these elements as a document. In this case, dissertation can be denoted as $\mathbf{D}=\left\{S_{1}, \ldots, S_{s}, A_{1}, \ldots, A_{a}, C_{1}, \ldots, C_{c}, R_{1}, \ldots, R_{r}, P_{1}, \ldots, P_{p}, G\right\}$. Denote the total number of documents in this set as $n$ :

$$
n=s+a+c+r+p+1,
$$

where $s$ is the number of chapters, $a$ is the number of articles, $c$ is the number of conference papers, $r$ is the number of results obtained in the dissertation, $p$ is the number of posed tasks. It is accepted that, the goal $\mathbf{G}$ is a separate document, that is $|\mathbf{G}|=1$, where $|\mathbf{U}|$ denotes the number of elements of set $\mathbf{U}$.

We denote a set of documents $\mathbf{D}$ as follows: $\mathbf{D}=\left\{d_{1}, d_{2}, \ldots, d_{n}\right\}$, where the first $s$ number of 
documents denote chapters, next $a$ documents denote articles, next $c$ documents denote the conference papers, next $r$ documents denote the results, next $p$ documents denote the tasks and finally, the last $n$th document denotes the goal of dissertation. More precisely, $\left\{d_{1}, d_{2}, \ldots, d_{s}\right\}=\mathbf{S}$; $\left\{d_{s+1}, d_{s+2}, \ldots, d_{s+a}\right\}=\mathbf{A} ; \quad\left\{d_{s+a+1}, d_{s+a+2}, \ldots, d_{s+a+c}\right\}=\mathbf{C} ; \quad\left\{d_{s+a+c+1}, d_{s+a+c+2}, \ldots, d_{s+a+c+r}\right\}=\mathbf{R} ;$
$\left\{d_{s+a+c+r+1}, d_{s+a+c+r+2}, \ldots, d_{s+a+c+r+p}\right\}=\mathbf{P} ; d_{n}=d_{s+a+c+r+p+1}=\mathbf{G}$.

Now, we represent each document of the set $\mathbf{D}$ as a vector.

Document represenation, term weighting scheme and similarity measure. The most widely used method for document representation is Vector Space Model. Assume that $\mathbf{T}=\left\{T_{1}, T_{2}, \ldots, T_{m}\right\}$ is a set of terms is encountered in the set of documents $\mathbf{D}=\left\{d_{1}, d_{2}, \ldots, d_{n}\right\}$. According to this model, any non-negative number $w_{i j}$ is posed to each term $T_{j}$ in document $d_{i}$. Hence, each document is represented as $m$-dimensional vector $d_{i}=\left[w_{i 1}, w_{i 2}, \ldots, w_{i m}\right], i=1,2, \ldots, n$. As seen, the length of this vector is equal to the number of terms encountered in the set of documents D. Here, $w_{i j}$ denotes the weight of term $T_{j}$ in document $d_{i}$. This weight can be calculated with various methods. The most widely used method is TF*IDF (term frequency-inverse document frequency) scheme. According to this scheme $w_{i j}$ can be calculated as follows:

$$
w_{i j}=t f_{i j} \log \left(\frac{n}{n_{j}}\right),
$$

Here, $n_{j}$ is the number of documents, where term $T_{j}$ is encountered, $t f_{i j}$ is the frequency of term $T_{j}$ in document $d_{i}$ :

$$
t f_{i j}=\frac{n_{i j}}{\left|d_{i}\right|} .
$$

Here, $\left|d_{i}\right|$ is the total number of terms in document $d_{i}, n_{i j}$ is the number of appearence of term $T_{j}$ in document $d_{i}$.

The next step after the document representation is the determination of similarity measure between documents.

Cosine measure is used for the calculation of the similarity between documents of the set $\mathbf{D}$ . According to the definition, the cosine similarity between the documents $d_{i}=\left[w_{i 1}, w_{i 2}, \ldots, w_{i m}\right]$ and $d_{j}=\left\lfloor w_{j 1}, w_{j 2}, \ldots, w_{j m}\right\rfloor$ is determined as follows:

$$
\operatorname{sim}\left(d_{i}, d_{j}\right)=\cos \left(d_{i}, d_{j}\right)=\frac{\sum_{t=1}^{m} w_{i t} w_{j t}}{\sqrt{\sum_{t=1}^{m} w_{i t}^{2}} \cdot \sqrt{\sum_{t=1}^{m} w_{j t}^{2}}}, \quad i, j=1, \ldots, n .
$$

At the next stage, we propose an approach for preliminary automated examination of dissertation work. At this step, a approach is proposed for determining the similarity of the posed tasks to the chapters, the results to articles, similarity among chapters, similarity among articles and similarity of articles to the conference papers. Two types of assessment are applied in order to carry out this approach: expert and automated. The automated approach calculates the similarity between documents (between the posed tasks and the goal, the posed tasks and the chapters, the results and the articles, etc.) by using the above mentioned metric. The preliminary examination of dissertation work is carried out based on this calculated value. The expert approach employes 
binary assessment ( 0 and 1) and fuzzy assessment using linguistic variables. The linguistic variables and corresponding triangular fuzzy numbers (TFNs) are shown in Table 1.

Table 1

Linguistic variables for the assessment

of dissertation

\begin{tabular}{|l|c|}
\hline Linguistic variables & Corresponding TFNs \\
\hline Similar & $(6,7,8)$ \\
\hline Partly similar & $(5,6,7)$ \\
\hline Not similar & $(4,5,6)$ \\
\hline
\end{tabular}

Proposed method. Firstly, we consider the assessment of similarity of the posed tasks to the goal of dissertation.

1. Similarity assesment of the posed tasks to the goal of dissertation. For this purpose, the similarity of each issue to a dissertation work is calculated and Table 2 is obtained as a result.

Table 2

Similarity between the posed tasks and the goal of dissertation

\begin{tabular}{|c|c|c|c|}
\hline \multirow{2}{*}{ Tasks } & \multicolumn{3}{|c|}{ Goal $-d_{n}$} \\
\cline { 2 - 4 } & $B=\left\|b_{i}\right\|, i=k, \ldots, k+p-1$ & $F=\left\|f_{i}\right\|, i=k, \ldots, k+p-1$ & $\begin{array}{c}\text { Calculated } E=\left\|e_{i}\right\|, \\
i=k, \ldots, k+p-1\end{array}$ \\
\cline { 2 - 4 } & $b_{k}$ & $f_{k}$ & $e_{k}=\operatorname{sim}\left(d_{k}, d_{n}\right)$ \\
\hline$d_{k}$ & $b_{k+1}$ & $f_{k+1}$ & $e_{k+1}=\operatorname{sim}\left(d_{k+1}, d_{n}\right)$ \\
\hline$d_{k+1}$ & $\ldots$ & $\ldots$ & $\ldots$ \\
\hline$\ldots$ & $b_{k+p-1}$ & $f_{k+p-1}$ & $e_{k+p-1}=\operatorname{sim}\left(d_{k+p-1}, d_{n}\right)$ \\
\hline$d_{k+p-1}$ & & & \\
\hline
\end{tabular}

First algorithm: expert assessment. Two approaches will be employed during expert assessment: binary and fuzzy.

If we denote the similarity of the tasks to the goal as $b_{i} \in\{0,1\}$ $(i=\overline{k, k+p-1}, k=s+a+c+r+1) \quad$ in $\quad$ binary assessment and as $f_{i}$ $(i=\overline{k, k+p-1}, k=s+a+c+r+1)$ in fuzzy assessment (Table 2), then the following cases should be considered:

1) $\sum_{i=1}^{p} b_{i}=p$ or $\frac{1}{p} \sum_{i=1}^{p} f_{i}=(6,7,8)$. It implies that, all issues are similar to the goal, that is, the issues posed in the dissertation work help to achieve the goal.

2) $0<\sum_{i=1}^{p} b_{i}<p$. This implies that, the issues posed in the dissertation work are not relevant for reaching the goal, that is, some issues ( $p-\sum_{i=1}^{p} b_{i}$ number of issues) are not related to the goal of the dissertation work.

3) $(4.5,5.5,6.5) \leq \frac{1}{p} \sum_{i=1}^{p} f_{i}<(6,7,8)$. It implies that, the issues posed in the dissertation work are partly relevant for reaching the goal. 
4) $\sum_{i=1}^{P} b_{i}=0$ or $(4,5,6) \leq \frac{1}{p} \sum_{i=1}^{p} f_{i}<(4.5,5.5,6.5)$. It implies that, the posed issues has no relation to the goal. That is, the goal is stated in dissertation work, however, different tasks are considered.

Second algorithm: automated assessment. If $\forall i \quad e_{i} \geq \theta$, it implies that, the posed tasks help to achieve the goal. Otherwise, if $\exists i$ such that, $e_{i}<\theta$, the proposed solution of this task does not help to reach the stated goal. Here, $\theta$ is a boundary value which is determined experimentally.

The first case can easily be derived from the second case. Indeed, if we denote

$$
b_{i}=\left\{\begin{array}{ll}
1, & \text { if } \quad e_{i} \geq \theta \\
0, & \text { otherwise }
\end{array}, \quad i=k, \ldots, k+p-1\right.
$$

then the first case can be derived from this.

2. Similarity assesment between the posed tasks and the dissertation chapters. In this subsection, the similarity of each task to the chapters of dissertation is assessed (Table 3 ).

Table 3

Similarity of the posed tasks to the dissertation chapters

\begin{tabular}{|c|c|c|c|c|c|c|c|}
\hline Chapters & \multicolumn{2}{|c|}{$d_{1}$} & \multicolumn{2}{|c|}{$d_{2}$} & $\cdots$ & \multicolumn{2}{|c|}{$d_{s}$} \\
\hline$d_{k}$ & $b_{k 1}$ & $f_{k 1}$ & $b_{k 2}$ & $f_{k 2}$ & $\ldots$ & $b_{k s}$ & $f_{k s}$ \\
\hline$d_{k+1}$ & $b_{k+1,1}$ & $f_{k+1,1}$ & $b_{k+1,2}$ & $f_{k+1,2}$ & $\ldots$ & $b_{k+1, s}$ & $f_{k+1, s}$ \\
\hline$\ldots$ & $\ldots$ & $\ldots$ & $\ldots$ & & $\ldots$ & $\ldots$ & \\
\hline$d_{k+p-1}$ & $b_{k+p-1,1}$ & $f_{k+p-1,1}$ & $b_{k+p-1,2}$ & $f_{k+p-1,2}$ & $\ldots$ & $b_{k+p-1, s}$ & $f_{k+p-1, s}$ \\
\hline
\end{tabular}

First algorithm: expert assessment. Denote the assessment matrix as $B=\left\|b_{i j}\right\|_{\substack{i=k, k+p-1 \\ j=1, s}}$, $b_{i j} \in\{0,1\}$ for binary approach and $F=\left\|f_{i j}\right\|_{\substack{i=\overline{k, k+p-1} \\ j=1, s}}, \quad(k=s+a+c+r+1)$ for fuzzy approach (Table 3). In this method:

1) If $\exists i$ such that, $\sum_{j=1}^{s} b_{i j}=0$ or $\sum_{j=1}^{s} f_{i j}=(4,5,6)$, then the $i$-th issue is not addressed in any of chapters. This is considered to be the worst case.

2) If $\exists i$ such that, $\sum_{j=1}^{s} b_{i j}=s$ or $\sum_{j=1}^{s} f_{i j}=(6,7,8)$, then the $i$-th issue addresses in all chapters. This is considered to be the worst case.

Note: Here, it is assumed that, one task is not solved with various methods.

3) If $\exists j$ such that, $\sum_{i=k}^{k+p-1} b_{i j}=0$ or $\sum_{i=k}^{k+p-1} f_{i j}=(4,5,6)$, then the $j$-th chapter does not address any issue. This is considered to be the worst case.

4) If $\exists j$ such that, $\sum_{i=k}^{k+p-1} b_{i j}=k+p-1$ or $\sum_{i=k}^{k+p-1} f_{i j}=(6,7,8)$, then the $j$-th addresses all issues. This is acceptable and implies that, posed problems has been tackled in one chapter. Then, which issues are solved in other chapters? If other issues are addressed, these issues cannot 
be unrelated to the goal. If addressed issues are unrelated to the goal, it only serves to complete the word count requirements of the dissertation work.

5) If $\forall i \quad s>\sum_{j=1}^{s} b_{i j} \geq 1$, it implies that, the $i$-th issue is solved at least in one chapter. This is considered to be a good case.

If $(6,7,8)>\frac{1}{s} \sum_{j=1}^{s} f_{i j} \geq(4,5,6)$, this implies that, the $i$-th task is partly solved at least in one chapter.

6) If $\forall j \neq 1\left[\frac{k+p-1}{s}\right] \geq \sum_{i=k}^{k+p-1} b_{i j} \geq 1$, this implies that, the $j$-th chapter addresses at least one issue. This is considered to be a good case.

If $(4,5,6) \geq \sum_{i=k}^{k+p-1} f_{i j} \geq(6,7,8)$, it implies that, the $j$-th chapter provides a partial solution for at least one issue.

Second algorithm: automated assessment. Denote the assessment matrix as $E=\left\|e_{i j}\right\| \|_{\substack{i=\overline{k, k+p+1} \\ j=1, s}}$ ,$e_{i j} \in[0,1]$ (Table 4).

Table 4

Similarity of the posed tasks to dissertation chapters (automated)

\begin{tabular}{|c|c|c|c|c|}
\hline Tasks Chapters & $d_{1}$ & $d_{2}$ & $\ldots$ & $d_{s}$ \\
\hline$d_{k}$ & $e_{k 1}$ & $e_{k 2}$ & $\ldots$ & $e_{k s}$ \\
\hline$d_{k+1}$ & $e_{k+1,1}$ & $e_{k+1,2}$ & $\ldots$ & $e_{k+1, s}$ \\
\hline$\ldots$ & $\ldots$ & $\ldots$ & $\ldots$ & $\ldots$ \\
\hline$d_{k+p-1}$ & $e_{k+p-1,1}$ & $e_{k+p-1,2}$ & $\ldots$ & $e_{k+p-1, s}$ \\
\hline
\end{tabular}

If $\forall i \exists j$ such that, $e_{i j} \geq \theta$, then the issue $d_{i}$ is solved at least in one chapter.

The first case can be easily derived from the second case:

$$
b_{i j}=\left\{\begin{array}{ll}
1, & \text { if } e_{i j} \geq \theta \\
0, & \text { otherwise }
\end{array} .\right.
$$

3. Similarity assesment between the dissertation results and the articles. The similarity of each result to published articles is assessed. The results are reported in Table 5.

Table 5

Similarity of results to articles

\begin{tabular}{|c|c|c|c|c|c|c|c|}
\hline Articles & \multicolumn{2}{|c|}{$d_{s+1}$} & \multicolumn{2}{c|}{$d_{s+2}$} & \multicolumn{2}{c|}{$d_{s+a}$} \\
\hline$d_{l}$ & $b_{l, s+1}$ & $f_{l, s+1}$ & $b_{l, s+2}$ & $f_{l, s+2}$ & $\ldots$ & $b_{l, s+a}$ & $f_{l, s+a}$ \\
\hline$d_{l+1}$ & $b_{l+1, s+1}$ & $f_{l+1, s+1}$ & $b_{l+1, s+2}$ & $f_{l+1, s+2}$ & $\ldots$ & $b_{l+1, s+a}$ & $f_{l+1, s+a}$ \\
\hline$\ldots$ & $\ldots$ & $\ldots$ & $\ldots$ & $\ldots$ & $\ldots$ & $\ldots$ & $\ldots$ \\
\hline$d_{l+r-1}$ & $b_{l+r-1, s+1}$ & $f_{l+r-1, s+1}$ & $b_{l+r-1, s+2}$ & $f_{l+r-1, s+2}$ & $\ldots$ & $b_{l+r-1, s+a}$ & $f_{l+r-1, s+a}$ \\
\hline
\end{tabular}


First algorithm: expert assessment. Denote the assessment matrix as $B=\left\|b_{z t}\right\|_{\substack{z=\bar{l}(l+1+1,1 \\ t=s+1, s+a}}$, $b_{z t} \in\{0,1\}$ for binary case and $F=\left\|f_{z t}\right\|_{\substack{z=\overline{l, l+r-1} \\ t=s+1, s+a}},(l=s+a+c+1)$ for fuzzy approach (Table 5). In this method:

1) If $\exists z$ such that, $\sum_{t=s+1}^{s+a} b_{z t}=0$ or $\frac{1}{s+a} \sum_{t=s+1}^{s+a} f_{z t}=(4,5,6)$, it implies that, the $z$-th result of the dissertation work is not addressed in any article. This is considered to be the worst case.

2) If $\exists z$ such that, $\sum_{t=s+1}^{s+a} b_{z t}=a$ or $\frac{1}{s+a} \sum_{t=s+1}^{s+a} f_{z t}=(6,7,8)$, it implies that, the same result is published in all articles. This is considered to be the worst case.

3) If $\exists t$ such that, $\sum_{z=l}^{l+r-1} b_{z t}=0$ or $\frac{1}{l+r-1} \sum_{z=l}^{l+r-1} f_{z t}=(4,5,6)$, it implies that, the $t$-th published article does not contain any of dissertation results. This is considered to be the worst case.

4) If $\exists t$ such that $\mathrm{i}, \sum_{z=l}^{l+r-1} b_{z t}=l+r-1$ or $\frac{1}{l+r-1} \sum_{z=l}^{l+r-1} f_{z t}=(6,7,8)$, it implies that, all results are published in one article. This is considered to be a worst case.

5) If $\exists z$ such that, $\sum_{t=s+1}^{s+a} b_{z t} \geq 1$ or $\frac{1}{s+a} \sum_{t=s+1}^{s+a} f_{z t} \geq(6,7,8)$, it implies that, the $z$-th result is addressed at least in one article. This is considered to be a good case.

6) If $\exists t$ such that, $r>\sum_{z=l}^{l+r-1} b_{z t} \geq 1$, this implies that, the $t$-th article addresses at least one result. This is considered to be a good case.

If $(4,5,6)>\frac{1}{l+r-1} \sum_{z=l}^{l+r-1} f_{z t} \geq(6,7,8)$, it implies that, the $t$-th article addresses at least one result partly.

Second algorithm: automated assessment. Denote the assessment matrix as $E=\left\|e_{z t}\right\|_{t=\bar{z}=\overline{l, l+r+1}}, e_{z t, s+a} \in[0,1]$ (Table 6).

Table 6

Similarity of the results to articles (automated)

\begin{tabular}{|c|c|c|c|c|}
\hline Results & $d_{s+1}$ & $d_{s+2}$ & $\ldots$ & $d_{s+a}$ \\
\hline$d_{l}$ & $e_{l, s+1}$ & $e_{l, s+2}$ & $\ldots$ & $e_{l, s+a}$ \\
\hline$d_{l+1}$ & $e_{l+1, s+1}$ & $e_{l+1, s+2}$ & $\ldots$ & $e_{l+1, s+a}$ \\
\hline$\ldots$ & $\ldots$ & $\ldots$ & $\ldots$ & $\ldots$ \\
\hline$d_{l+r-1}$ & $e_{l+r-1, s+1}$ & $e_{l+r-1, s+2}$ & $\ldots$ & $e_{l+r-1, s+a}$ \\
\hline
\end{tabular}

If $\forall z \exists t$ such that, $0 \geq e_{z t} \geq \theta$, then the $z$-th result is published at least in one article. The first case can be easily derived from the second case: 


$$
b_{i t}=\left\{\begin{array}{ll}
1, & \text { if } e_{i t} \geq \theta \\
0, & \text { otherwise }
\end{array} .\right.
$$

4. Similarity assesment of the publihed journal articles. For this purpose, the similarity of each article with other articles published on the dissertation topic is assessed and Table 7 is obtained.

Table 7

Similarity of published articles

\begin{tabular}{|c|c|c|c|c|c|c|c|}
\hline Articles & \multicolumn{2}{|c|}{$d_{s+1}$} & \multicolumn{2}{c|}{$d_{s+2}$} & \multicolumn{2}{c|}{$d_{s+a}$} \\
\hline$d_{s+1}$ & $b_{s+1, s+1}$ & $f_{s+1, s+1}$ & $b_{s+1, s+2}$ & $f_{s+1, s+2}$ & $\ldots$ & $b_{s+1, s+a}$ & $f_{s+1, s+a}$ \\
\hline$d_{s+2}$ & $b_{s+2, s+1}$ & $f_{s+2, s+1}$ & $b_{s+2, s+2}$ & $f_{s+2, s+2}$ & $\ldots$ & $b_{s+2, s+a}$ & $f_{s+2, s+a}$ \\
\hline$\ldots$ & $\ldots$ & $\ldots$ & $\ldots$ & $\ldots$ & $\ldots$ & $\ldots$ & $\ldots$ \\
\hline$d_{s+a}$ & $b_{s+a, s+1}$ & $f_{s+a, s+1}$ & $b_{s+a, s+2}$ & $f_{s+a, s+2}$ & $\ldots$ & $b_{s+a, s+a}$ & $f_{s+a, s+a}$ \\
\hline
\end{tabular}

First algorithm: expert assessment. Denote the assessment matrix as $B=\left\|b_{q t}\right\|_{\substack{q=\overline{s+1, s+a} \\ t=s+1, s+a}}$, $b_{q t} \in\{0,1\}$ and $F=\left\|f_{q t}\right\|_{\substack{q=\overline{s+1, s+a} \\ t=s+1, s+a}}$ for fuzzy aproach (Table 7).

1) It is obvious that, only head diagonal elements of this matrix must equal 1 , rest of elements must be equal to zero: $b_{q q}=1, b_{q t}=0, q \neq t$. That is, if $\forall q \sum_{t=s+1}^{s+a} b_{q t}=1$ or $\frac{1}{s+a} \sum_{t=s+1}^{s+a} f_{q t}=(6,7,8)$ and $\forall t \sum_{q=s+1}^{s+a} b_{q t}=1$ or $\frac{1}{s+a} \sum_{q=s+1}^{s+a} f_{q t}=(6,7,8)$. This is considered to be the best case.

2) If $\exists z$ such that, $a \geq \sum_{t=s+1}^{s+a} b_{z t}>1$, it implies that, some of the articles published on the dissertation topic coincide, that is, the same article is published with different titles. This is considered to be a very bad case.

Second algorithm: automated assessment. Denote the assessment matrix as $E=\left\|e_{q t}\right\| \|_{\substack{q=s+1, s+a \\ t=s+1, s+a}}$ $, e_{q t} \in[0,1], e_{q t}=1, z=t$ (Table 8).

Table 8

Similarity of articles (automated)




If $\forall t \neq q \exists t$ such that, $e_{q t}=0$, then, none of the articles coincides with the topic of another article. The first case can be easily derived from the second case:

$$
b_{z t}= \begin{cases}1, & \text { if } \quad e_{q t} \geq \theta \\ 0, & \text { otherwise }\end{cases}
$$

5. Similarity assesment of the tasks of dissertation and the conference papers. For this purpose, the similarity of each task to published conference papers is evaluated and results are reported in Table 9.

Table 9

Similarity of tasks to conference papers

\begin{tabular}{|c|c|c|c|c|c|c|c|}
\hline $\begin{array}{r}\text { Conference } \\
\text { papers }\end{array}$ & \multicolumn{2}{|c|}{$d_{s+a+1}$} & \multicolumn{2}{c|}{$d_{s+a+2}$} & \multicolumn{2}{c|}{$d_{s+a+c}$} \\
Tasks & \multicolumn{2}{|c|}{$\ldots$} & \multicolumn{3}{c|}{} \\
\hline$d_{k}$ & $b_{k, s+a+1}$ & $f_{k, s+a+1}$ & $b_{k, s+a+2}$ & $f_{k, s+a+2}$ & $\ldots$ & $b_{k, s+a+c}$ & $f_{k, s+a+c}$ \\
\hline$d_{k+1}$ & $b_{k+1, s+a+1}$ & $f_{k+1, s+a+1}$ & $b_{k+1, s+a+2}$ & $f_{k+1, s+a+2}$ & $\ldots$ & $b_{k+1, s+a+c}$ & $f_{k+1, s+a+c}$ \\
\hline$\ldots$ & $\ldots$ & $\ldots$ & $\ldots$ & & $\ldots$ & $\ldots$ & $\ldots$ \\
\hline$d_{k+p-1}$ & $b_{k+p-1, s+a+1}$ & $f_{k+p-1, s+a+1}$ & $b_{k+p-1, s+a+2}$ & $f_{k+p-1, s+a+2}$ & $\ldots$ & $b_{k+p-1, s+a+c}$ & $f_{k+p-1, s+a+c}$ \\
\hline
\end{tabular}

First algorithm: expert assessment. Denote the assessment matrix as $B=\left\|b_{i f}\right\|_{i=\overline{k, k+p-1}}$, $b_{i f} \in\{0,1\}$ and $F=\left\|f_{i f}\right\|_{i=\overline{k, k+p-1}}$ for fuzzy approach (Table 9).

1) It is clear that, one issue can be addressed in one or several approbations. Each line of a given matrix must contain at least one "1".

2) If $\exists i$ such that, $\sum_{f=s+a+1}^{s+a+c} b_{i f}=0$ or $\frac{1}{s+a+c} \sum_{f=s+a+1}^{s+a+c} f_{i f}=(4,5,6)$, it implies that, the $i$-th issue of dissertation work is not addressed on any approbation.

3) If $\exists f$ such that, $\quad \sum_{i=k}^{k+p-1} b_{i f}=0$ or $\frac{1}{k+p-1} \sum_{i=k}^{k+p-1} f_{i f}=(4,5,6)$, it is implied that, the $f$-th approbation does not address any issue of dissertation work. This is considered to be a worst case.

4) If $\exists i$ such that, $\sum_{f=s+a+1}^{s+a+c} b_{i f}=c$ or $\frac{1}{s+a+c} \sum_{f=s+a+1}^{s+a+c} f_{i f}=(6,7,8)$, it is implied that, all issues are approbated. This is considered to be a good case.

5) If $\exists f$ such that, $\sum_{i=k}^{k+p-1} b_{i f}=p$ or $\frac{1}{k+p-1} \sum_{i=k}^{k+p-1} f_{i f}=(6,7,8)$, it is implied that, all issues posed in dissertation work are addressed in approbation. This is considered to be a good case.

6) If $\exists i$ such that, $\sum_{f=s+a+1}^{s+a+c} b_{i f} \geq 1$ or $\frac{1}{s+a+c} \sum_{f=s+a+1}^{s+a+c} f_{i f} \geq(6,7,8)$, it is implied that, the $i$-th issue has been addressed at least in several approbations. This is considered to be a good case. 
7) If $\exists f$ such that, $\sum_{i=k}^{k+p-1} b_{i f} \geq 1$ or $\frac{1}{k+p-1} \sum_{i=k}^{k+p-1} f_{i f} \geq(6,7,8)$, it is implied that, the $f$-th approbation addresses at least one issue. This is considered to be a good case.

Second algorithm: automated assessment. Denote the assessment matrix as $E=\left\|e_{i f}\right\|_{i=\frac{k, k+p+1}{f=s+a+1, s+a+c}}$, wher $e_{i f} \in[0,1]$ (Table 10).

Table 10

Similarity of tasks to conference papers (automated)

\begin{tabular}{|c|c|c|c|c|}
\hline \multirow{2}{*}{ Tasks Conference papers } & $d_{s+a+1}$ & $d_{s+a+2}$ & $\ldots$ & $d_{s+a+c}$ \\
\hline$d_{k}$ & $e_{k, s+a+1}$ & $e_{k, s+a+2}$ & $\ldots$ & $e_{k, s+a+c}$ \\
\hline$d_{k+1}$ & $e_{k+1, s+a+1}$ & $e_{k+1, s+a+2}$ & $\ldots$ & $e_{k+1, s+a+c}$ \\
\hline$\ldots$ & $\ldots$ & $\ldots$ & $\ldots$ & $\ldots$ \\
\hline$d_{k+p-1}$ & $e_{k+p-1, s+a+1}$ & $e_{k+p-1, s+a+2}$ & $\ldots$ & $e_{k+p-1, s+a+c}$ \\
\hline
\end{tabular}

If $\forall i \exists f$ such that, $e_{i f} \geq \theta$, then issue $d_{i}$ is addressed at least in one approbation.

The first case can be easily derived from the second case:

$$
b_{i f}=\left\{\begin{array}{ll}
1, & \text { if } \quad e_{i f} \geq \theta \\
0, & \text { otherwise }
\end{array} .\right.
$$

Moreover, the distribution of the dissertation pages accross chapters, the recognition of journals approved by Higher Attestation Commission where articles have been published and the correspodence to specialty code can be checked. In addition, the distribution of the published articles and approbations accross years, the distribution of referenced sources accross dissertation chapters, years and countries can be checked and the topicality of the problem can be assessed.

\section{Conclusion}

The method proposed for the assessment of disseratation works is based on expert assessment, as well as on automated assessment. In this case, models have been proposed which assess the similarity of posed issues to dissertation goal, the similarity of posed issues to chapters, the addressing of dissertation results in articles, the similarity of articles to each other and approbation of posed issues. The time and resources spent on the assessment of dissertation works can be saved by employing these models.

\section{Conflict of interest}

We declare that we have no financial and personal relationships with other people or organizations that can inappropriately influence our work, there is no professional or other personal interest of any nature or kind in any product, service and/or company that could be construed as influencing the position presented in, or the review of, the article entitled, "A method for preliminary examination of dissertations". The study was conducted by the authors, no other people involved in conceiving, performing, and writing this study. 


\section{References}

1. Seletkov S.G. To the applicant of a scientific degree // Izhevsk State. tech. University, 1999, $174 \mathrm{p}$.

2. Kuzin F.A. Ph.D. thesis. Method of writing, design rules and defense procedure. A practical guide for graduate students and candidates for a scientific degree. 6th ed., Ext., M .: Os-89, 2004, 224 p.

3. Phillips E.M., Pugh D.S. How to Get a PhD: A handbook for students and their supervisors. USA: Open University Press, 2005, 234 p.

http://library.ciitlahore.edu.pk/hub/How_to_get_PhD.pdf

4. Bird J. Black students and higher education. Buckingham: SRHE and Open University Press 1996.

5. Wason P.C. Notes on the supervision of PhDs. Bulletin of the British Psychological Society 1974, vol.27, pp.25-29.

6. Salmon P. Achieving a PhD: Ten Students' Experience. Stoke-on-Trent: Trentham Books, 1992.

7. Rugg G., Petre M. The Unwritten Rules of PhD Research. Maidenhead: Open University Press, 2004.

8. Murray R. How to Write a Thesis. Buckingham: Open University Press, 2002.

9. Kiley M., Mullins G. Examining the examiners: How inexperienced examiners approach the assessment of research theses // International Journal of Educational Research, 2005, vol.41, no.2, pp.121-35.

10. Holbrook A., Bourke S., Lovat T. Investigating $\mathrm{PhD}$ thesis examination reports // International Journal of Educational Research, 2004, pp 98-120.

11. Denicolo P. Assessing the PhD: A constructive view of criteria // Quality Assurance in Education, 2003, vol.11, no.2, pp.84-91.

12. Wright T. Cochrane R. Factors influencing successful submission of $\mathrm{PhD}$ theses // Studies in Higher Education, 2000, vol.2, no.25, pp.181-195.

13. Kyvik S. Assessment procedures of Norwegian $\mathrm{PhD}$ theses as viewed by examiners from the USA, the UK and Sweden // Assessment and Evaluation in Higher Education, 2014, vol.39, no.2, pp.140-53.

14. Aittola H. Doctoral Education and Doctoral Theses - Changing Assessment Practices. Cultural Perspectives on Higher Education, 2008, pp.161-177.

15. Aittola H. Academic life and the pressure of massification. In Välimaa J. (ed.) Finnish higher education in transition. Perspectives on massification and globalisation. University of Jyväskylä: Institute for Educational Research 2001, pp.111-138.

16. Mullins G, Kiley M. It's a PhD, not a Nobel Prize: How experienced examiners assess research theses // Studies in Higher Education, 2002, vol.27, no.4, pp.369-386.

17. Hagen NT. Deconstructing doctoral dissertations: How many papers does it take to make a $\mathrm{PhD}$ ? // Scientometrics, 2010, vol.85, no.2, pp.567-579.

18. Kyvik $\mathrm{S}$, Thune T. Assessing the quality of $\mathrm{PhD}$ dissertations. A survey of external committee members // Assessment \& Evaluation in Higher Education, 2015, vol.40, no.5, pp.768-782.

19. Bourke S, Holbrook AP. Examining $\mathrm{PhD}$ and research masters theses // Assessment \& Evaluation in Higher Education, 2013, vol.38, no.4, pp.407-416. 


\section{Oliquliyev Rasim M. ${ }^{1}$, Alıquliyev Ramiz M. ${ }^{2}$, Həsənova Rəhilə Ş. ${ }^{3}$}

AMEA İnformasiya Texnologiyaları İnstitutu, Bak1, Azərbaycan

1‥alguliev@gmail.com, ${ }^{2}$ r.aliguliyev@gmail.com, ${ }^{3}$ rahasanova@gmail.com

\section{Dissertasiya işlərinin ilkin qiymətləndirilməsi metodu}

Məqalədə dissertasiya işlərinin qiymətləndirilməsi üçün beynəlxalq təcrübə araşdırılmışdır. Dissertasiya işlərinin avtomatlaşdırılmış qiymətləndirilməsi üçün metod təklif edilmişdir. Bu məqsədlə ilkin ekspertizanın avtomatlaşdırılması üçün alqoritm işlənmişdir. Bu metod dissertasiya işinin əsas hissələri (dissertasiya işinin məqsədi, qarşıya qoyulmuş məsələlər, fəsillər, əldə edilmiş nəticələr, dərc edilmiş məqalələr) arasındakı uyğunluğu avtomatik təyin etməyə imkan verir. Bu məqsədlə mətnlərin semantik yaxınlığını müəyyənləşdirməyə imkan verən mətnlərin intellektual analizi texnologiyası tətbiq edilir. Təklif edilən metod və ekspert qiymətləndirilməsi arasındakı uyğunluğu təyin etmək üçün qiymətləndirmə verilmişdir.

Açar sözlor: dissertasiya, mətnlorin intellektual analizi, avtomatik qiymətləndirmə, ekspert qiymatlandirmasi, qeyri-salis qiymatlandirma

\section{УДК 001:004.7}

\section{Алгулиев Расим М. ${ }^{1}$, Алыгулиев Рамиз М. ${ }^{2}$, Гасанова Рахиля Ш. ${ }^{3}$}

Институт Информационных Технологий НАНА, Баку, Азербайджан

${ }^{1}$ r.alguliev@gmail.com, ${ }^{2}$ r.aliguliyev@gmail.com, ${ }^{3}$ rahasanova@gmail.com

\section{Метод для предварительной оценки диссертационных работ}

В статье исследуется международная практика оценки диссертационных работ. Предложен метод автоматической оценки диссертационных работ. В связи с этим были разработаны алгоритмы автоматизации предварительной экспертизы. Этот метод позволяет автоматически определять сходство основных частей диссертации (цель диссертационной работы, задачи, главы, полученные результаты, опубликованные статьи). Для этого применяется технология Text Mining, которая позволяет определять семантическую близость текстов. Оценивается соответствие между предлагаемым методом и экспертной оценкой.

Ключевые слова: диссертация, text mining, автоматическая оценка, экспертная оценка, нечеткая оценка. 